\title{
A PSZICHOLÓGIAI TANÁCSADÁS SZAKMAI ALAPPROTOKOLLJA (RECENZIÓ)
}

A recenzió szerzője:

Olteanu Lucián Líviusz (Drs)

Eszterházy Károly Egyetem

Szerző e-mail címe:

luciolteanu@gmail.com
Lektorok:

Szabóné Balogh Ágota (PhD)

Gál Ferenc Főiskola

Lestyán Erzsébet (PhD)

Gál Ferenc Főiskola

...és további két anonim lektor

Olteanu Lucián Líviusz (2019): A pszichológiai tanácsadás szakmai alapprotokollja (recenzió). OxIPO - interdiszciplináris tudományos folyóirat, 2019/4, 89-91.

doi: 10.35405/OXIPO.2019.4.89

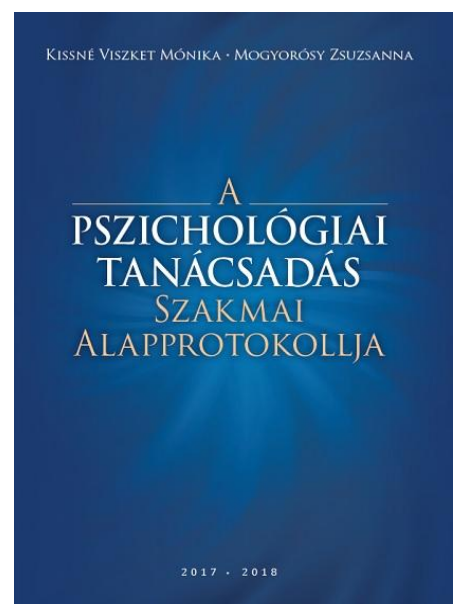

Jelen recenzió alapjául szolgáló mủ bibliográfiája:

Kissné Viszket Mónika - Mogyorósy Zsuzsanna (2019): A Pszichológiai Tanácsadás Szakmai Alapprotokollja. ELTE Ötvös Kiadó, Budapest. 84 oldal ISBN 978963-489-085-0

Kulcsszavak: pszichológiai tanácsadás, alapprotokoll, tanácsadói folyamat

Diszciplina: pszichológia

Bibliography of the subject of this recension: Kissné Viszket Mónika - Mogyorósy Zsuzsanna (2019): Professional Basic Protocol of Psychological Counseling. Budapest (HU): ELTE Ötvös Kiadó, Budapest. pp. 84 ISBN 978-963-489-085-0

Keywords: psychological counseling, basic protocol, counseling process

Discipline: psychology 
A könyv szerzői a pszichológiai tanácsadás szakterületének hazai gyakorlói, oktatói.

Dr. Kissné Viszket Mónika: egyetemi adjunktus, Eötvös Lóránd Tudományegyetem Pedagógiai és Pszichológiai Kar klinikai szakpszichológus, pszichoterapeuta-jelölt tanácsadó szakpszichológus.

Dr. Mogyorósy-Révész. Zsuzsanna: tanácsadó szakpszichológus, felnőtt EMDR (szemmozgásokkal történő deszenzitizálás és újrafeldolgozás) terapeuta.

A pszichológiai tanácsadás szakmai alapprotokollja koherens képet nyújt a téma iránt érdeklődőknek. Struktúráját tekintve következetes, ami segíti a megértést. Fontos szerepet játszik a szakmai útmutatók körében, vagyis a protokollok, sztenderdek, irányelvek, eljárásrendek, jó gyakorlatok hierarchiájában. A kiadvány elsődleges célja, hogy segítse a pszichológiai tanácsadást, mint a szakterület munkáját és emellett a szakmai rendszerekben való elhelyezését.

A 84 oldal terjedelmű könyv összesen 15 fejezetből áll, beleértve a bevezetést és az összefoglalást is. A bevezetést követően, az 1 . fejezetben a szerzők röviden áttekintik a hazai tanácsadói pszichológia alakulását, mely fókuszában az egyén egész élettartamára jellemző erősségek és adaptív stratégiák fejlődési perspektívái találhatóak.

A 2. fejezetben az alapprotokoll keretrendszerével ismerkedik meg az olvasó, mely definiálja a pszichológiai tanácsadást, rövid történeti áttekintést nyújt a pszichológiai tanácsadás helyzetéről, továbbá bemutatja a szerkezetét, felépítését és az alapprotokoll típusait.
A 3. fejezetben a pszichológiai tanácsadás alapprotokolljának jogszabályi környezete, képzési szabályzása, munkavégzési szabályzása és a személyes adatok védelme kerül fókuszba, amely meghatározza azokat a rendszereket és tevékenységeket, melyek a tanácsadó pszichológusokra vonatkoznak.

A 4. fejezetben a pszichológiai tanácsadás képzési és foglalkoztatási rendszere, hazai szabályozása, a pszichológiai szaktanácsadást mutatják be az írók.

Az 5. fejezetben a pszichológiai tanácsadás meghatározása, a tevékenység definíciója kerül bemutatásra, melyet több pszichológiai aspektusból járnak körbe.

A 6. fejezetben a pszichológiai tanácsadás kompetencia modelljeit, a hazai és a nemzetközi szervezetek tanácsadói kompetenciarendszereit tárgyalják a Szerzők. Ezek a rendszerek elméleti alapokra építenek, a képzések bázisát adják, illetve új, komplex megközelítéseket jelentenek.

A 7. fejezetben a tanácsadó szakpszichológusi tevékenységének célcsoportjait mutatják be az alapprotokollban, majd a hazai a tanácsadó szakpszichológusok célcsoportjaikkal kapcsolatos tapasztalataikat részletezik. Végül pedig kitekintést kapunk a nemzetközi tapasztalataikról is.

A 8. fejezetben az etikai megfontolások kapnak helyet, míg a 9. fejezetben a pszichológiai tanácsadás ellátásához szükséges infrastruktúráról írnak a szerzôk.

A 10. fejezetben a pszichológiai tanácsadás folyamatáról, ebben a kiemelten fontos fogalmak meghatározásáról, a folyamat modelljeiről, folyamatábrájának részletező leírásáról 
és az eljárásrend kifejtésének meghatározását mutatják be. Az alapprotokoll arra törekszik, hogy az ellátás kiegyenlített minőségének megteremtése érdekében egy egységes iránymutató folyamatmodellt adjon, amely a pszichológiai tanácsadás kereteit határozza meg.

A 11. fejezetben a pszichológiai tanácsadás eszközeit tárgyalják - a tanácsadó pszichológus által mérésre alkalmazható különböző eszközöket (tesztek, becslőskálák, kérdőívek).

A 12. fejezetben a pszichológiai tanácsadásban történő adminisztrációt mutatják be, míg a 13. fejezetben a szakmai és szakmaközi kommunikáció hazai és nemzetközi gyakorlatára térnek ki.

A 14. fejezetben a tanácsadó szakpszichológusok szakmai munkájának a támogatását, az esetmegbeszélő és szupervíziókat és a továbbképzési lehetôségeket tárgyalják.

Végül a 15. fejezetben a tanácsadó szakpszichológusi szakmai munka minőségellenőrzésének hazai és nemzetközi gyakorlata kerül bemutatásra.

Az alapprotokoll igyekszik a meglévő pszichológiai protokollok rendszerét követni, (elsődlegesen a szakszolgálati alapprotokoll struktúrája az irányadó, melynek célja a közös tevékenységi területekkel való harmonizálása).

A könyvet pszichológusoknak, tanácsadó szakpszichológusoknak ajanlom. Az alapprotokoll igyekszik egy egységes rendszerrel se- gítséget nyújtani azzal, hogy a tevékenységüket rendezetten, áttekinthetően mutassa be mind szűk szakmai köröknek, mind a szabályozótestületek számára. Továbbá a mű törekszik arra, hogy rögzítse a ma érvényben lévő szabályozásokat, áttekintést adjon a nemzetközi tapasztalatokról, a tanácsadás folyamatmodelljével, alapvető tanácsadói fogalmak definiálásával szakmai útmutatást jelentsen. Különösen figyelemre méltó, mivel egy nagyon jó rendszerszemléletû megközelítést ad a pszichológiai tanácsadás szakmai követelményeiről és kézzelfogható segítséget, útmutatás nyújt elméleti és gyakorlati szinten egyaránt.

\section{Hivatkozások}

Kissné Viszket, M., és Mogyorósy, Zs. (2019). A pszichológiai tanácsadás szakmai alapprotokollja. Budapest: ELTE Eötvös Kiadó. Letöltve: 2019. 10. 13-án: http://www.eltereader.hu/media/2019/0 6/Kissne_Viszket_Pszich_tanacsadas_W EB.pdf

Kissné Viszket. M., és Mogyorósy, Zs. (2017). A Pszichológiai Tanácsadás Szakmai Alapprotokollja - A tanácsadói folyamat. Alkalmazott Pszichológia 17(4):45-66. DOI: $\underline{\text { 10.17627/ALKPSZICH.2017.4.45 }}$ 